\title{
WAŻNIEJSZE SPOTKANIA POLITYKÓW POLSKI ORAZ KRAJÓW AZJI I PACYFIKU (STYCZEŃ-PAŹDZIERNIK 2007)
}

\section{0-30.03}

Marszałek Senatu RP Bogdan Borusewicz wraz z grupą parlamentarzystów przebywał z oficjalną wizytą w Nowej Zelandii i Australii. Delegacji towarzyszyła grupa polskich przedsiębiorców.W Wellington polscy parlamentarzyści uczestniczyli w sesji poświęconej 50. rocznicy podpisania traktatów rzymskich, spotkali się z przewodniczącą Izby Reprezentantów Nowej Zelandii Margaret Wilson, członkami rządu oraz przedstawicielami Polonii. W Australii - rozmawiali m.in. z przewodniczącym Izby Reprezentantów Davidem Hawkerem, przewodniczącym Senatu Paulem Calvertem, ministrem spraw zagranicznych Alexandrem Downerem, a także przedstawicielami Polonii.

\section{2-24.04}

Na zaproszenie prezydenta RP oficjalną wizytę w Polsce złożył prezydent Pakistanu, Generał Pervez Musharraf. W historii stosunków dyplomatycznych między obu krajami była to pierwsza wizyta prezydenta Pakistanu w Polsce. Prezydentowi Musharrafowi towarzyszyli federalni ministrowie, członkowie parlamentu oraz wysocy dygnitarze. W trakcie wizyty P. Musharraf spotkał się z prezydentem Lechem Kaczyńskim oraz odbył rozmowy z premierem Jarosławem Kaczyńskim. Podczas spotkań rozmawiano o potrzebie zacieśnienia relacji między Pakistanem a Polską, zwłaszcza w zakresie gospodarki i handlu, o możliwościach współpracy w dziedzinie sektora obronnego oraz w zakresie edukacji i kultury, a także o sytuacji międzynarodowej. Podpisane zostały: Program Współpracy w Dziedzinie Kultury, Nauki i Edukacji między Rządem Rzeczypospolitej Polskiej a Rządem Islamskiej Republiki Pakistanu na lata 2007-2009, Umowa o Współpracy między Urzędem ds. Rozwoju Małych i Śred- 
nich Przedsiębiorstw Rządu Pakistanu a Polską Agencją Rozwoju Przedsiębiorczości, Deklaracja o Współpracy Obronnej, Porozumienie o Współpracy między Izbami Handlu i Przemysłu obu krajów.

\subsection{4}

Minister obrony Pakistanu Rao Sikandar Iqbal spotkał się z ministrem obrony narodowej Aleksandrem Szczygło, z którym omówił kwestie związane z udziałem polskich żołnierzy w misji w Afganistanie oraz wsparciem Pakistanu dla walki z terroryzmem.

\subsection{5}

Minister A. Szczygło zakończył wizytę w Pakistanie (i Afganistanie). Podczas pobytu w Islamabadzie, A. Szczygło spotkał się z ministrem obrony Pakistanu, z którym rozmawiał m.in. o zacieśnieniu współpracy służb wywiadowczych w kontekście zabezpieczenia misji polskich żołnierzy w Afganistanie, współpracy przemysłu zbrojeniowego i uczelni wojskowych.

\section{4-25.05.}

W Polsce przebywał przewodniczący Ogólnochińskiego Zgromadzenia Przedstawicieli Ludowych Wu Bangguo. Program wizyty obejmował spotkania z prezydentem Lechem Kaczyńskim oraz premierem Jarosławem Kaczyńskim. Obie rozmowy dotyczyły stosunków dwustronnych pomiędzy Polską a Chińską Republiką Ludową, ze szczególnym uwzględnieniem współpracy gospodarczej, a także kwestii międzynarodowych. W obecności premiera RP i przewodniczącego OZPL zostały podpisane umowy między rządami Polski i Chin: Protokół między Ministerstwem Kultury i Dziedzictwa Narodowego a Ministerstwem Kultury ChRL o Współpracy Kulturalnej na lata 2007-2011, Protokół dot. Warunków Sanitarnych Eksportu Polskiego Mięsa Drobiowego do Chin pomiędzy Ministerstwem Rolnictwa i Rozwoju Wsi RP a Naczelną Administracją Kontroli Jakości i Kwarantanny ChRL oraz Porozumienie pomiędzy Ministerstwami Zdrowia Polski i Chin o Wspólpracy w Dziedzinie Opieki Zdrowotnej i Nauk Medycznych. Przewodniczący Wu Bangguo złożył ponadto wizytę w Senacie, gdzie przeprowadził rozmowę z marszałkiem Bogdanem Borusewiczem, a także w Sejmie, gdzie spotkał się z marszałkiem Ludwikiem Dornem.

\section{8-29.05}

Minister spraw zagranicznych RP, Anna Fotyga uczestniczyła 8. Spotkaniu Ministrów Spraw Zagranicznych ASEM (Asia Europe Meeting) w Hamburgu. Agenda spotkania obejmowała szeroki zakres tematów, m.in.: wydarzenia regionalne i międzynarodowe, politykę energetyczną i zmiany klimatyczne, walkę z terroryzmem, nieproliferację oraz współpracę w w dziedzinie ekonomicznej, kulturalnej i społecznej. Podczas pobytu w Hamburgu minister A. Fotyga wzięła również udział w spot- 
kaniu ministrów spraw zagranicznych krajów Grupy Wyszehradzkiej i Japonii, jak też przeprowadziła dwustronne rozmowy z ministrami spraw zagranicznych Chińskiej Republiki Ludowej Yang Jiechi, Indii Pranabem Mukherjee oraz Mongolii Nymaa Enkhboldem.

\section{0-31.05}

Z wizytą w Polsce przebywał minister spraw zagranicznych Japonii Taro Aso, który odbył rozmowy z minister spraw zagranicznych Anną Fotygą oraz został przyjęty przez prezydenta Lecha Kaczyńskiego. W trakcie rozmowy omówiono zagadnienia dwustronne, zwłaszcza w kontekście obchodów 50. rocznicy wznowienia stosunków dyplomatycznych między obydwoma państwami. Poruszano także kwestie międzynarodowe, $m$ in. dotyczące sytuacji w Azji Północno-Wschodniej.

\section{7-21.06}

Marszałek Ludwik Dorn wraz z delegacją Sejmu złożył oficjalną wizytę w Republice Korei, gdzie odbył rozmowy z czołowymi politykami koreańskimi: prezydentem Roh Moo-Hyunem, przewodniczącym Zgromadzenia Narodowego Republiki Korei Lim Chae-Jungiem, z ministrem spraw zagranicznych i handlu Song Min-Soonem oraz liderami największych klubów parlamentarnych. Podczas rozmów poruszano m.in. tematy związane z zacieśnianiem polsko-koreańskiej współpracy parlamentarnej i gospodarczej. Delegacja polska odwiedziła także strefę zdemilitaryzowaną między Koreą Południową i Północną.

\subsection{9}

Z oficjalną wizytą przebywał w Polsce premier Socjalistycznej Republiki Wietnamu Nguyen Tan Dung. Rozmowy szefa wietnamskiego rządu z premierem Jarosławem Kaczyńskim dotyczyły spraw gospodarczych oraz współpracy w innych dziedzinach, m.in. w sferze edukacji i kultury, a także kwestii związanych z licznie zamieszkującymi w Polsce obywatelami Wietnamu. Premier Nguyen Tan Dung złożył również wizyty marszałkowi Sejmu Ludwikowi Dornowi oraz marszałkowi Senatu Bogdanowi Borusewiczowi.

\subsection{9}

Minister Anna Fotyga, stojąca na czele polskiej delegacji podczas sesji otwierającej obrady Zgromadzenia Ogólnego NZ, spotkała się w Nowym Jorku z ministrem spraw zagranicznych Australii Alexandrem Downerem. 27. 09 minister A. Fotyga spotkała się z ministrem spraw zagranicznych Singapuru Georgem Yong-Boon Yeo.

\section{4-5.10.}

W Warszawie odbyło się XX. Posiedzenie Rady Gubernatorów Fundacji Azja-Europa (ASEF). Zostało ono zorganizowane w 10. rocznicę powstania Fundacji, która 
ma swą siedzibę w Singapurze i jest jedynym zinstytucjonalizowanym mechanizmem współpracy w ramach ASEM. Celem Fundacji jest promowanie kontaktów pomiędzy społeczeństwami Azji i Europy oraz rozwoju wzajemnego zrozumienia między kontynentami w czterech programach: Intellectual Exchange, People to People Exchange, Cultural Exchange, Public Affairs. W ramach tych programów realizowanych jest szereg projektów, w których uczestniczą kraje członkowskie ASEM. Polska jest członkiem ASEF od momentu przystapienia do Unii Europejskiej w 2004 r. W trakcie spotkania przyjęte zostały sprawozdania z rocznej działalności poszczególnych programów, a także plan działania na lata 2008-2010.

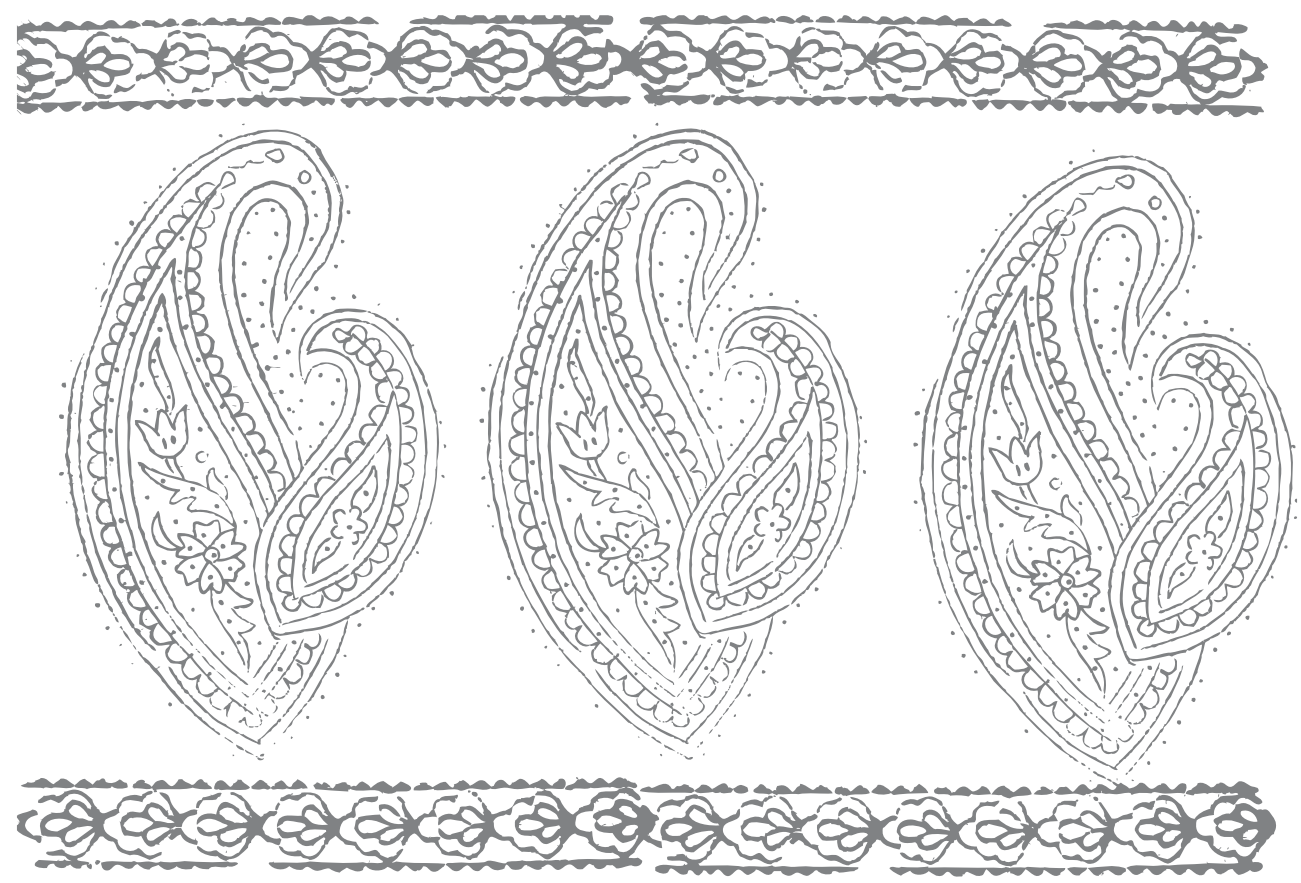

